\author{
FINAL PROGRESS REPORT - MARCH 1990-AUG 1992 \\ USDOE CONTRACT DE FG02 87 ER60547
}

\author{
Project Title: Measurement and Apportionment of Radon Source \\ Terms for Modeling Indoor Environments \\ Organization: NYU Medical Center \\ Department of Environmental Medicine \\ 550 Eirst Avenue \\ New York, NY 10016
}

\footnotetext{
Principal Investigator: Naomi H. Harley, Ph.D., Res. Professor

Phone : $212-263-5287$

EAX : :212 - $263-7190$

EMAIL :Harley@NYUMED.BITN
}

\title{
DISCLAIMER
}

This report was prepared as an account of work sponsored by an agency of the United States Government. Neither the United States Government nor any agency thereof, nor any of their employees, makes any warranty, express or implied, or assumes any legal liability or responsibility for the accuracy, completeness, or usefulness of any information, apparatus, product, or process disclosed, or represents that its use would not infringe privately owned rights. Reference herein to any specific commercial product, process, or service by trade name, trademark, manufacturer, or otherwise does not necessarily constitute or imply its endorsement, recommendation, or favoring by the United States Government or any agency thereof. The views and opinions of authors expressed herein do not necessarily state or reflect those of the United States Government or any agency thereof. 
During the present $21 / 2$ year contract period, we have made significant progress in modeling the source apportionment of indoor ${ }^{222} \mathrm{Rn}$ and in ${ }^{222} \mathrm{Rn}$ decay product dosimetry.

Two additional areas were worked on which we believe are useful for the DOE Radon research Program. One involved an analysis of the research house data, grouping the hourly house ${ }^{222} \mathrm{Rn}$ measurements into 2 day, 7 day and 90 day intervals to simulate the response of passive monitors. These data showed that even though the measured annual average in the energy efficient home was $2.7 \mathrm{pCi} 1^{-1}\left(100 \mathrm{~Bq} \mathrm{~m}^{-3}\right)$ a short term measurement as defined by these intervals would yield data above $4 \mathrm{pCi} \mathrm{I}^{-1}\left(150 \mathrm{~Bq} \mathrm{~m}^{-3}\right)$ the EPA guideline $20 \%$ of the time. The only measurement that would yield an accurate estimate of the actual annual average was the average of two, 90 day measurements.

A manuscript was prepared for the DOE Science Writers symposium in May 1991 and was widely circulated within EPA. Considerable effort was spent with persons in EPA to show that short term measurements are useless in decision making if the home is near the EPA guideline. EPA persists in the myth that these short term measurements are definitive at ${ }^{222} \mathrm{Rn}$ concentrations near the guideline.

This is a very important area as enormous funds will be spent in remediation of homes that do not require remediation (false positives).

Another area requiring some attention resulted in a publication of 3 years of our indoor/outdoor measurements in a high-rise apartment. Little interest has been evinced in apartment measurements yet $20 \%$ of the U.S. population lives in multiple-family dwellings, not in contact with the ground. These data together with a summary of all other published data on apartments showed that apartments have only about $50 \%$ greater ${ }^{222} \mathrm{Rn}$ concentration than the measured outdoor ${ }^{222} \mathrm{Rn}$. Apartment dwellers generally represent a low risk group regarding ${ }^{222} \mathrm{Rn}$ exposure. detail.

The following sections describe the main projects in some MODELING INDOOR ${ }^{222} \mathrm{Rn}$

A model that describes indoor ${ }^{222} R$ n well in two research homes located in northern $\mathrm{NJ}$ and under the same air mass has been developed. The model utilizes a log transform of the ${ }^{222} \mathrm{Rn}$ data, and regiession with the various factors known to affect indoor 
concentrations, i.e., indoor/outdoor temperature difference, barometric pressure changes, wind, rain and outdoor ${ }^{222} \mathrm{Rn}$. Temperature and wind speed variables must be lagged to obtain best fit of the model to the data. The major factors that influence indoor ${ }^{222} \mathrm{Rn}$ concentrations are outdoor temperature and barometric pressure changes in an energy efficient home and these factors plus outdoor ${ }^{222} \mathrm{Rn}$ in a 75 year old wood frame house.

The ${ }^{222} \mathrm{Rn}$ measurements are recorded hourly in two homes located in northern New Jersey. The homes are $80 \mathrm{~km}$. apart and are under the same air mass as determined by barometric and temperature changes. One home is an ultra-high energy efficient home and the other a 75 year old wood frame home.

The energy efficient home was constructed with ${ }^{222} \mathrm{Rn}$ mitigation features. There is a bed of crushed rock, a polyethylene sheet and a layer of sand under the home. A porous PVC pipe network was installed under the slab in the event that an active ${ }^{22} \mathrm{Rn}$ mitigation system was needed. There is an air to air heat exchanger and the ventilation rate in the home is governed by this unit. The interior from floor to floor is open and vaulted with wide staircases. The measured ${ }^{222} \mathrm{Rn}$

concentration is similar on all floors.

Radon measurements in this home are made hourly in the basement and on the second floor. a series of sensors that measure pressure difference across the slab (two locations), temperature (four indoors and two outdoors), relative humidity, barometric pressure, and wind speed sample at about one minute intervals and record the average data hourly through an $\mathrm{ADC}^{1}$. The annual average ${ }^{222} \mathrm{Rn}$ concentration is $120 \mathrm{~Bq} \mathrm{\textrm {m } ^ { - 3 }}$ throughout the home.

The old style frame house has double glazing and storm windows but lacks the tight structure of the energy efficient home. There is a full basement with poured cindercrete walls. Above the basement there are two floors and an attic. A smali work room was added to the basement with concrete block walls and this is used as an experimental room as the influx of ${ }^{222} \mathrm{Rn}$ is
higher.

In this home, ${ }^{222} \mathrm{Rn}$ measurements are made hourly in the basement, in the workroom and outdoors. Four sensors measure pressure differential across the slab; six temperature sensors measure the basement, work room, attic, outdoors, and soil temperature. There are relative humidity, a barometric pressure and wind speed sensors, and these record average data hourly.

${ }^{1}$ Remote Measurement Systems, Inc., Seattle, WA 98102 
In the energy efficient house, the ventilation rate is essentially a constant, determined by the setting of the heat exchanger. In the old frame house the ventilation rate can also increase with colder outdoor temperatures, further decreasing indoor ${ }^{222} \mathrm{Rn}$.

The data selected were for one half season in winter 1991. All sensors were operative during this period. The data file was first thinned by selecting measurements made every 3 rd hour ( 8 per day). The regression coefficients and the multiple correlation coefficient, $\mathrm{R}^{2}$, values are shown in the manuscript in the Appendix. For the energy efficient home. The best fit was obtained by lagging the temperature for 6 hours, the wind speed by 3 hours, the rain by 6 hours. The peaks due to barometric pressure drop were best fit by summing the change in barometric pressure (delta BP) over 9 hours prior to the actual ${ }^{222} \mathrm{Rn}$ measurement. The best fit with outdoor ${ }^{222} \mathrm{Rn}$ was obtained with no time lag.

The outdoor temperature (or indoor outdoor temperature difference) was the major variable with negative correlation $\left(R^{2}=50 \%\right)$, barometric pressure second $\left(R^{2}=15 \%\right)$ and wind, rain and outdoor ${ }^{222} \mathrm{Rn}$ in decreasing order of importance.

A plot of the model along with the measured ${ }^{222} \mathrm{Rn}$ concentrations for both homes is shown in the manuscript in the Appendix.

The regression equation for this home is, $\operatorname{Ln}\left({ }^{222} R n\right)=5.00-0.031 \mathrm{~T}_{(\text {out }-1 n) 6}-0.014 \mathrm{DBP}_{6}-0.018$ Wind $_{3}+0.034 \mathrm{Rain}_{6}+0.005 \mathrm{Rn}_{\text {out }}$ where $\mathrm{T}_{\text {in-out }}=$ Indoor/outdoor temperature difference lagged 6 hours prior to the ${ }^{222} \mathrm{Rn}$ measurement $\left({ }^{\circ} \mathrm{C}\right)$. $\mathrm{DBP}_{9}=$ barometric pressure difference over a 9 hour interval prior to the ${ }^{222} \mathrm{Rn}$ measurement. Wind $\mathrm{W}_{3}=$ wind speed lagged 3 hours prior to the ${ }^{222} \mathrm{Rn}$ ... - - measurement ...(m $\left.\sec ^{-1}\right)$. $\operatorname{Rain}_{6}=$ rainfall 6 lagged hours prior to the ${ }^{222} \mathrm{Rn}$ ${ }^{222} \mathrm{Rn}_{\text {out }}=$ outdoor ${ }^{222} \mathrm{Rn}$ concentration, no lag $\left(\mathrm{Bq} \mathrm{m} \mathrm{m}^{-3}\right)$.

A comparison of the measured ${ }^{222} \mathrm{Rn}$ concentrations in both homes located under the same air mass (see manuscript) shows that the same meteorological factors (temperature and barometric pressure) are controlling indoor ${ }^{222} \mathrm{Rn}$. This fact is quantitated by the similarity in the regression equations. 
The model can be used to evaluate the influence of each factor. For example, for the energy efficient home, if no barometric pressure drops had occurred during the interval, the average ${ }^{222} \mathrm{Rn}$ concentration would have been $10 \%$ lower. The measured average ${ }^{222} \mathrm{Rn}$ concentration over the interval was $82 \mathrm{~Bq}$ $\mathrm{m}^{-3}$ for the measured average temperature difference, $\mathrm{T}_{1 \text {-out }}$ of $22^{\circ} \mathrm{C}$. If the average temperature difference during this period were only $10^{\circ} \mathrm{C}$ the ${ }^{222} \mathrm{Rn}$ concentration would have been $30 \%$ higher.

The constant term in the two equations is the steady state concentration for the house, resulting from entry by diffusion and the removal by ventilation. An indoor/outdoor temperature difference caused by decreasing outdoor temperature induces a pressure difference across the slab. However, as air is drawn into the basement through the soil, replacement outdoor air with low ${ }^{222} \mathrm{Rn}$ concentration is drawn into the soil ventilating around and under the hoise. The net effect is to reduce the ${ }^{222}$ Rn entry rate with resulting lower indoor ${ }^{222} \mathrm{Rn}$ concentrations. For this reason the temperature difference term for both houses is negative. Wind also acts to ventilate under the dwelling and the coefficient of this term in the equations is also ragative.

This manuscript was submitted to the journal Health Physics in.July-1992 and the-measurements presented at the annual Health Physics meeting in June 1992.

\section{BIOMODELING ${ }^{222}$ Rn DECAY PRODUCT DOSE}

The alpha dose per unit exposure from ${ }^{222} \mathrm{Rn}$ decay products to basal and mucous cell nuclei in bronchial epithelium has been modeled using detailed information on nucleus location, mucus thickness, nasal deposition for submicrometer and micrometer sized particles, airway deposition, physical dosimetry and atmospheric particle size characteristics. The dose is modeled for two situations, underground mine atmospheres and normal indoor ervironments. The dose per unit exposure is the same for both situations with a maximum difference of a factor of two depending upon the atmospheric characteristics used. The most appropriate dose conversion factor for the historical mines appears to be from 9 to $13 \mathrm{mGy} \mathrm{WLM}^{-1}$ and for homes from 9 to 10 mGy WLM $^{-1}$. Cigarette smoke aerosol in homes can reduce the factor somewhat. The difference in the dose conversion factor between average characteristics assumed for mines and homes is considered negligible and supports the use of lung cancer risk estimates in miners directly for use in the indoor environment.

In the past few years, much of the data now available for modeling dose from ${ }^{22} \mathrm{Rn}$ decay products has become available through research supported by the DOE Radon Research Program. Data on the deposition of typical particles associated with ${ }^{222} \mathrm{Rn}$ 
decay products in casts of the human lung (Cohen and Asgharian 1990), deposition of submicron sized particles in the nose and mouth (Cheng et al 1988, 1990), the thickness of the layer of mucus on bronchial epithelium (Mercer et al. 1991) and the depth and density of target cell nuclei in the epithelium (Robbins et al. 1990).

Without additional specific data, differences in the alpha dose per unit exposure should be considered negligible. This supports the use of lung cancer risk estimates calculated from underground mining exposure directly in environmental situations.

This manuscript was submitted to the journal Health Physics in November 1991 and the measurements presented at the annual Health Physics meeting in June 1991. We receinved the reviews in august 1992 and the editors say thay are interested in publishing once the correctios suggested by the reviewers are made.

\section{A BIOLOGICALLY BASED RISK MODEL FOR LUNG CANCER DUE TO ${ }^{222} \mathrm{Rn}$ EXPOSURE}

A significant finding of the BEIR IV committee and in the work of Sevc et al reported at this conference, is not only the verification in the reduction in risk with time since exposure, but the additional finding of reduction in risk with attained age, the $\gamma(a)$ factor. In the BEIR IV model this is a dramatic: reduction factor, i.e., 0.4 at age 65 versus 1.0 with attained age 55. The reason for the two separate factors requires a biological explanation.

It is important to interpret the results of a mathematical model in terms of the underlying biological principles. If these are not in agreement, the models can not be thought of as mechanistic but merely fitting an artificial model to data. Many models can be well fit to data without the true analytical features being known.

One plausible explanation for the observations in the Colorado miner data is as follows.

The target cells for bronchogenic carcinoma are iocated in the thin layer of epithelium lining the bronchial airways. The target cells can be basal cells, the classical stem cells for repopulating epithelium, or the more recently implicated secretory cells (Johnson and Hubbs 1990, Boren and Paradise 1978, McDowell et al. 1978, Reid and Jones 1979, Ayers and Jeffery 1988, Breuer et al 1990, Harmon et al 1991). Both cell types lie within the range of alpha particles emitted by ${ }^{222} \mathrm{Rn}$ decay products deposited on the airway surfaces (Robbins 1992). 
The epithelium constantly regenerates itself by cell division. This turnover rate for the cells in bronchial epithelium is relatively low compared to other well studied epithelia such as the epidermis or intestinal lining. The turnover rate is not well documented. The division of a scem cell, however, to replace a lost or dying cell, maintains the number of celis in the epithelium at a constant number per unit area. It is important to know whether this number changes with age and smoking status.

The only data of this kind is currently being established in measurements by Robbins et al (1992). Preliminary data on the cell density in a 27 and 61 year old nonsmoker, and in a 69 year old smoker show that the cell density in the nonsmokers does not change appreciably with age. The cell density for the smoker is significantly less.

Scant information in the literature for cell turnover rate in the rat indicate that the turnover rate decreases with age (Reid and Jones 1978, Ayers and Jeffery 1988). These facts may be brought into a biological model of cell survival and division in the epithelium.

The current philosophy concerning carcinogenesis is that lung cancer originates from a single damaged cell. The damaged or initiated cell may not divide for many years, during which time it can acquire the necessary changes for transformation to a cell with the potential for carcinogenesis upon division. During the period of dormancy, there is a finite probability that this cell will be lost.

The probability for loss can be expressed as the fractional removal due to the replacement process within a group of cells. This is most likely an exponential function.

area.

$$
\begin{aligned}
& d Q / d t=P-\lambda Q=0 \\
& \text { where } \begin{aligned}
P & =\text { production rate of cells. } \\
\lambda & =\text { cell removal rate. } \\
Q & =\text { steady state number of cells per unit }
\end{aligned}
\end{aligned}
$$

In order to establish a steady state, cell production must equal cell loss. However, the removal rate, $\lambda$, is not thought to be constant over time but a decreasing function with age. If this is true, the production rate must also decrease to accomodate the observed constancy of cell density in nonsmokers with age in preliminary data of Robbins (Harley and Robbins 1992).

The survival of any cell irradiated at time $t_{0}$, at time $t$, 
can therefore be expressed as,

$$
S=\operatorname{Exp}\left[-\lambda\left(t-t_{0}\right)\right]
$$

The probability of a particular cell dividing is,

$$
\dddot{\mathrm{P}}(t)=\lambda \mathrm{s}
$$

Estimates of the reduction in turnover rate, $\lambda$, in the rat are that it decreases by about a factor of two over the life span. Assuming a linear relationship in the turnover rate, $\lambda$,

$$
\lambda=\left(K_{1}-K_{2} \text { age }\right)
$$

The probability of a potential cancer cell dividing at a particular age as a function of time post exposure, (age- $t_{0}$, is
then

$$
P\left(\text { age } \mid t_{0}\right)=\left(K_{1}-K_{2} \text { age }\right) \operatorname{Exp}\left[-\left(K_{1}-K_{2} \text { age }\right)\left(\text { age }-t_{0}\right)\right]
$$

Lung cancer following exposure at $t_{0}$, can be modelled by including a risk coefficient to normalize the expression.

$$
R\left(t \mid t_{0}\right)=R C\left[P\left(a g e \mid t_{0}\right)\right]
$$

where $\mathrm{RC}=$ risk coefficient, cases year ${ }^{-1} \mathrm{WLM}^{-1}$

The introduction of $\lambda$ as a function other than linear produces important changes in the model. Inclusion as an exponential, for example, would simply change the overall removal constant and the effect of attained age could not be distinguished from a simple time since exposure process. The biological model accommodates the observation in the miners data that risk is reduced with time since exposure and with attained age.

Any of the models derived so far that introduce at least two parameters, could be fit to the observed miner data by selecting appropriate parameters. The biological model has the advantage that it is a mechanistic model and this type of model is desireable.

Smoking is an important problem which must be considered in modeling ${ }^{222} \mathrm{Rn}$ lung cancer risk because smoking alone is such a significant carcinogen.

The fraction of lung cancer in smokers in exposure groups from 500 to 3000 WLM were plotted versus the fraction of lung cancer in nonsmokers for the same exposure. The data were for the 5-14 year duration exposure group. The maximum exposure category is $3000 \mathrm{WLM}$ and the total fractions of lung cancer at 
this exposure are 0.12 and 0.045 in smokers and nonsmokers respectively.

It was shown that the cumulative data follow a reasonably straight line indicating that ${ }^{222} \mathrm{Rn}$ induced lung cancer for smokers is a constant factor times that in nonsmokers (smokers have about a factor of 2 greater risk than nonsmokers for the same ${ }^{222} \mathrm{Rn}$ exposure). This does not imply that a multiplicative model is correct but rather that the two are related by this ratio.

The data were presented at the International Symposium for Safety in Uranium Mines at Saskatoon, Saskatchewan, Canada in May 1992. The manuscript is in the proceedings.

\section{DOSE TO ORGANS OTHER THAN THE LUNG EROM ${ }^{222} \mathrm{R}$ AND DECAY PRODUCTS}

The alpha dose to cells in tissues or organs other than the lung has been calculated using the solubility coefficients for ${ }^{222} \mathrm{Rn}$ measured in human tissue. The annual alpha dose equivalent from ${ }^{222} \mathrm{Rn}$ and decay products in most tissues is a maximum of $30 \%$ of the annual average natural background dose equivalent ( $1 \mathrm{mSv})$ for external and internally deposited nuclides (not including the dose equivalent for ${ }^{222} \mathrm{Rn}$ decay products to cells in bronchial airways). The dose to the small population of lymphocytes located in or under the bronchial epithelium is a special case and their annual dose equivalent is essentially the same as that to basal cells in bronchial epithelium (200 mSv) for continuous exposure to $200 \mathrm{~Bq} \mathrm{~m} \mathrm{~m}^{-3}$. The significance of this dose is uncertain because the only excess cancer observed in follow up studies of underground miners with high ${ }^{222} \mathrm{Rn}$ exposure is bronchogenic carcinoma.

The dose values reported have been calculated using conventional uniform tissue dosimetry for blood and soft tissue, using dosimetry developed from measured stopping power data for cells in bronchial airways and alveolar tissue and using the dosimetry developed by us for cells on bone surfaces and in marrow.

The major risk from ${ }^{222} \mathrm{Rn}$ decay products results from irradiation of basal. and mucous cell nuclei in bronchial epithelium ${ }^{(8)}$. The annual dose equivalent to these cell nuclei for an indoor concentration of $200 \mathrm{~Bq} \mathrm{~m}^{-3}$ is about $200 \mathrm{mSv}$.

The same magnitude alpha dose equivalent is delivered to lymphocytes in or under bronchial epithelium as to basal cell nuclei. Lymphocytes in bronchial epithelium are a small fraction of the lymphocyte population. Their abundance is a few percent 
of that of basal cells in bronchial epithelium. Jeffrey et al. measured the fraction of these intraepithelial inigratory cells that are lymphocytes as 60 and 908 of the total. Most of the lymphocytes present in bronchial epithelium are $T$ lymphocytes. Both $T$ and $B$ lymphocytes have the potential to be stem cells for lymphoma although the consequence of their irradiation and possible mutation is unknown. Bronchial epithelial lymphocytes may be in the process of exiting the body since they have been recovered in bronchial lavage. Bosanko et al. (1991) reported that although rare, primary pulmonary lymphoma does occur. The fact remains that follow up studies of underground miners document only excess lung cancer.

The data were presented at the Natural Radiation Environment $V$ Symposium in Salzberg, Austria in September 1991. The manuscript will appear in the journal Radiation protetion Dosimetry.

\section{INDOOR/OUTDOOR ${ }^{222} \mathrm{Rn}$ IN THAILAND}

Most ${ }^{222} \mathrm{Rn}$ measurements whether indoor or outdoor have been made in cold or temperate regions. There is little interest in ${ }^{222} \mathrm{Rn}$ in warm climate areas because the obvious free air exchange with outdoor concentration affords small opportunity for indoor

${ }^{222} \mathrm{Rn}$ enhancement.

It is necessary to acquire some measured data, however, to investigate whether the study of special populations may be of value. In the case where outdoor concentrations are elevated or depressed, an entire area may be subjected to a limited range of exposure, either high or low, and this could be useful in defining human exposure accurately and investigating health effects.

We have developed a passive ${ }^{222}$ Rn monitor utilizing a solid state nuclear track detector (SSNTD), CR-39, to perform high quality measurements at low ${ }^{222} \mathrm{Rn}$ exposures (Litt et al. 1991, Harley et al. 1991). The passive monitor has a lower limit of detection of $2.2 \mathrm{kBq} \mathrm{h} \mathrm{m}$. The background tracks on the pristine alpha track film are $4 \pm .16 \quad(n=281)$ with a calibration factor of $2.56 \pm .03$ tracks per $\mathrm{kBq} \mathrm{h} \mathrm{m} \mathrm{m}^{-3}$ for a $9 \times 9 \mathrm{~mm}$ film $(n=53)$. Validation studies with the monitor are reported by litt 1991.

The SSNTD film has a protective layer on both sides and alpha tracks over and above the inherent background tracks are 
not accumulated until the protective layer is stripped of $f^{2}$. The films are sent by mail and replaced, approximately seasonally, in the monitors by the homeowners. At retrieval, the exposed film is placed in a ziplock plastic bag and this terminates further accumulation of alpha tracks. Control SSNTD's with the protective layer in place are sent with each field batch. The protective coating on the controls is peeled off by the homeowner only at retrieval and the film placed in a ziplock bag. All detectors are etched overnight upon arrival at New York University in $6 \mathrm{~N} \mathrm{KOH}$. Positive controls exposed in the U.S. Department of Energy Environmental Measurements Laboratory ${ }^{22 i_{R n}}$ calibration chamber, pristine blank detectors and the control blanks mailed to the homeowner are etched with each batch of field samples.

The passive monitors were deployed in 2 homes in Bangkok and in 6 homes in the principal northern city, Chiang Mai. One of the homeowners in Chiang Mai also placed a passive detector in his office at the university, which was on the second floor of the building. All homes in the study are two story with the exception of Houses 4 and 6 in Chiang Mai.

Indoor and outdoor measurement-s of ${ }^{222} \mathrm{Rn}$ were made in these homes in Bangkok and Chiang Mai, Thailand, intermittently over a 3 year period. Indoor and outdoor ${ }^{222} \mathrm{Rn}$ concentrations were the same, as expected in a tropical climate. Average concentrations in Bangkok were $12 \mathrm{~Bq} \mathrm{~m}^{-3}$, similar to outdoor measurements in most countries and in Chiang Mai $42 \mathrm{~Bq} \mathrm{~m}^{-3}$, similar to the reported U.S. average. No seasonal changes were seen in Bangkok but a strong seasonal cycle was observed in Chiang Mai with high concentrations occurring during the dry period.

A tropical climate offers a relatively controlled ${ }^{222} \mathrm{Rn}$ exposure to a population and may provide a special group for the study of health effects.

This manuscript was submitted to the journal Health physics in July 1992 and the measurements presented at the annual Health Physics meeting in June 1992 .

2 Laser cut by Tech/Ops Landauer Glenwood Science Park, Glenwood, IL 60425 
MANUSCRIPTS PUBLISHED OR SUBMITTED DURING THE CONTRACT INTERVAL MARCH 1990 TO AUGUST 1992

Harley and Fisenne

The Distribution and Alpha Radiation Dose from Naturally Occurring $U, T h$ and $R a$ in the Human skeleton

Health Physics 58, 515-518, 1990

Harley, Terilli

Predicting Annual Average ${ }^{222} \mathrm{Rn}$ Exposure

Health Physics 59, 205-209, 1990

Scarpitta, Harley

Adsorption and desorption of noble gases on activated charcoal: I. ${ }^{133} \mathrm{Xe}$ studies in a monolayer and packed bed Health Physics 59, 383-392, 1990

Scarpitta, Harley

Adsorption and desorption of noble gases on activated charcoal: II. ${ }^{222} \mathrm{Rn}$ studies in a monolayer and packed bed Health Physics 59, 393-404, 1990

Spencer, Osis, Fisenne, Perry, Harley-

Measured Intake and Excretion Patterns in Humans for Naturally Occuring ${ }^{234} \mathrm{U}$ and ${ }^{238} \mathrm{U}$

Radiation Research $124,90-95,1990$

Harley

Does 4 eaual 2? Decisions based on radon measurements. Am. J. Public Health, 80, 906-906, 1990

Harley, N., Harley, J.

Potential lung cancer risk from indoor radon exposure

CA-A Cancer Journal for Clinicians,

40 (Sept-Oct), 265-275, 1990

Scarpitta, Harley

An improved ${ }^{222} \mathrm{Rn}$ canister using a two-stage charcoal system

Health Physics, 60, 177-188, 1991

Harley

Radon levels in a high-rise apartment

Health Physics 61, 263-265, 1991

Litt, Waldman, Harley, Chittaporn

Validation of a personal radon monitor for use in residential exposure studies

Health Physics 61, 727-735, 1991 
Harley, Chittaporn

Personal and home radon and gamma-ray measured in 52 dwellings Health Physics 61, 737-744, 1991

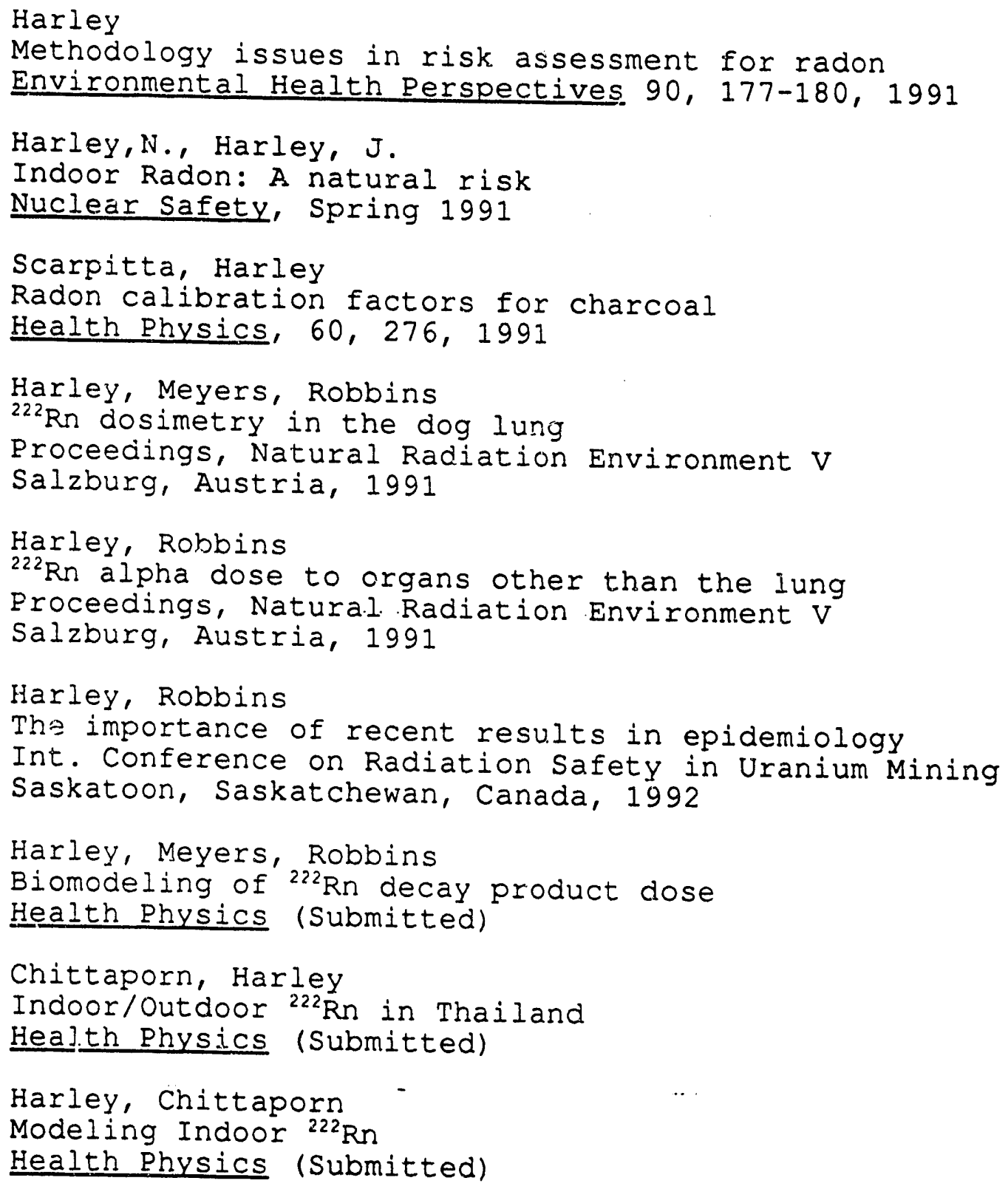


REFERENCES

Ayers, M.M., and Jeffrey, P.K., Proliferation and differentiation in mammalian airway epithelium. Eur. Resp. J. 1, 59-80, (1988).

Boren, H.G. and Paradise, L.J., Cytokinetics of lung. In Pathogenesis and therapy of lung cancer C.C. Harris Ed. Marcel Decker, NY pp 369-117, (1978).

Bosanko, C.M., Korobkin, M., Fantone, J.C., Rubin, S.B., Iynch, J.P., Lobar primary pulmonary lymphoma:CT findings. J. Comp. Assisted Tomography 15, 679-682 (1991).

Brever, R., Zajicek, G., Christensen, T.G., Lucey, E.C., and Snider, G.L., Cell kinetics of normal adult hamster bronchial epitheium in the steady state. Am. J. Resp. Cell Mol. Biol. 2,. $51-58,(1990)$.

Cheng, Y.S.; Yamada, Y.; Yeh, H.C.; Swift, D.L. Diffusional deposition of ultrafine aerosols in a human nasal cast. J. Aerosol Sci. 19: 741752; (1988).

Cheng, Y.S.; Yamada, Y.; Yeh, H.C.; "' Swift, D.I. Deposition of ultrafine aerosols in a human oral cast. Aerosol Sci. Tech. 12: 1075-1081; (1990).

Cohen, B.S.; Asgharian, B. Deposition of ultrafine particles in the upper airways: An empirical analysis. J. Aerosol Sci. 21: $789-797$; (1990).

Litt, Waldman, Harley, Chittaporn

Validation of a personal radon monitor for use in residential exposure studies

Health Physics 61, 727-735, (1991)

Harley, N.H., Chittaporn, P. Personal and home radon and gamma-ray measured in 52 dwellings Health Physics 61, 737-744, (1991)

Harley, N.H., Robbins, E.S.

The importance of recent results in epidemiology

Int. Conference on Radiation Safety in Uranium Mining

Saskatoon, Saskatchewan, Canada, (1992)

Harmon, K.R., Marinelli, W.A., Heute, C.A., Bitterman, P.B., Regulation of cell replication. In: The Iung: Scientific Foundation. R.G. Crystal et al Eds. Raven Press, NY pp 105-129, (1991).

Johnson, N.F. Hubbs, A.F., Epithelial progenitor cells in the 
- rat trachea. Am. J. Resp. Cell Mol. Biol. 3, 579-585, (1990).

MCDowell, E.M., Barrett, I.A., Glavin, F., Harris, C.C. and Trump, B.E., The respiratory epithelium. I. Human bronchus. J. Nat. Can. Inst. 61, 539-549; (1978).

Mercer, R.R.; Russell, M.I.; Crapo, J.D. Radon dosimetry based on the depth distribution of nuclei in human and rat lungs. Health Phys. 61: 117-130; (1991).

Reid, I., and Jones, R., Bronchial mucosal cells. Fed. Proc. 38, 191-196, (1979).

Robbins, E.S.; Meyers, O.A.; Harley, N.H. Quantification of the nuclei of human bronchial epithelial cells from electron microscopy for radon risk analysis. Proc. XIIth International Congress for Electron Microscopy: 228-229; (1990).

Robbins, E.S., Meyers, O.A., Harley, N.H. Target cells in lung carcinogenesis: Human bronchial morphometry, Epithelial Cell Biology (Submitted) 

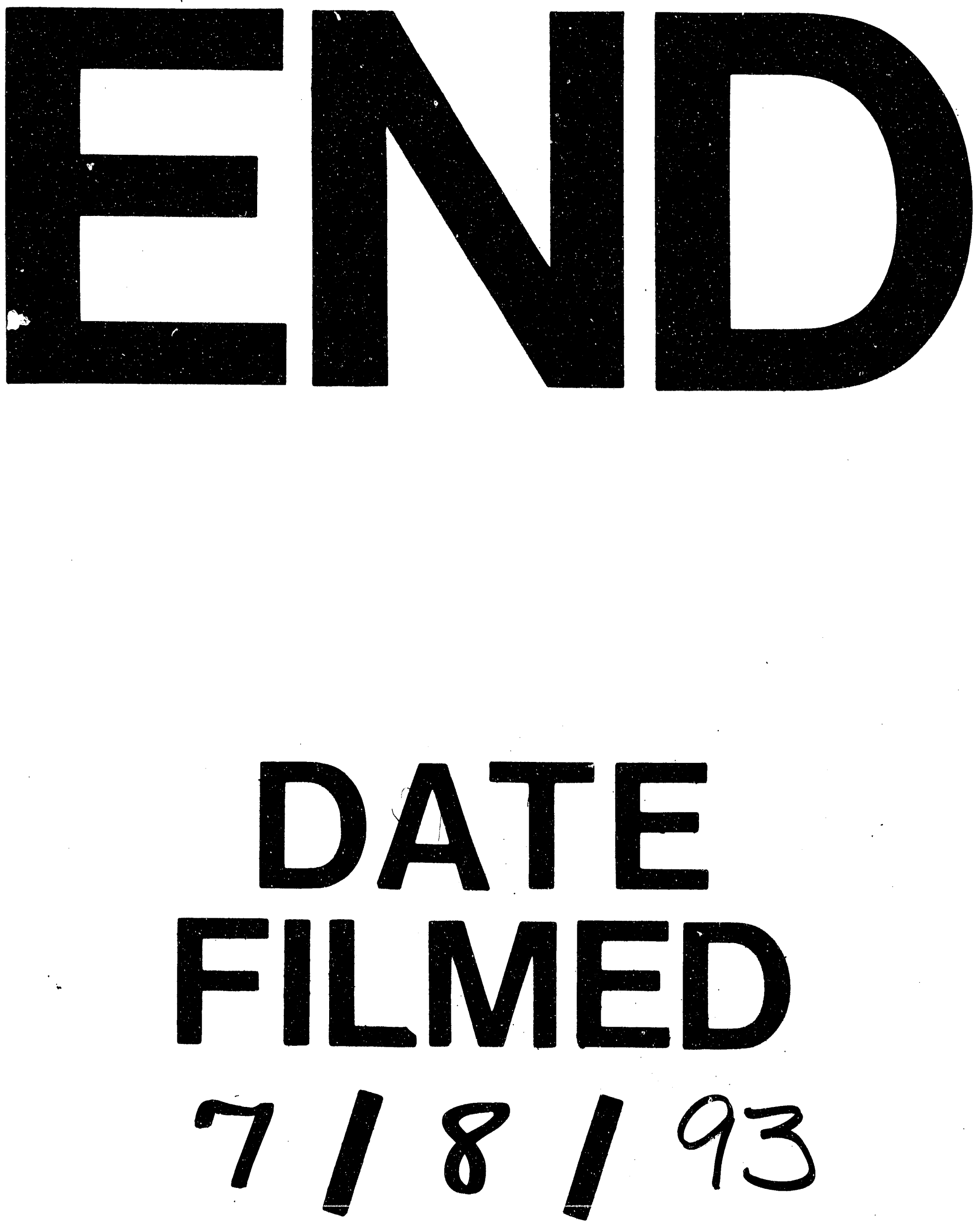
